\title{
Experimental Study on Concrete by Replacing Fine Aggregate Partially with Copper Slag
}

\author{
G. Ezhilarasan ${ }^{1}$, \\ ${ }^{1}$ Post Graduation student, \\ Department of Civil Engineering, \\ Sri Krishna College of Technology, \\ Tamil Nadu, India
}

\author{
E. Harsha Babu², S. Karthik Raj ${ }^{3}$, P. Esakkiraj ${ }^{4}$, \\ ${ }^{2,3,4}$ Post Graduation student, \\ Department of Civil Engineering, \\ Sri Krishna College of Technology, \\ Tamil Nadu, India
}

\begin{abstract}
Copper slag is a copper industry waste that is essentially used as an abrasive for metals to remove coatings or paintings, due to its hardness, sieve distribution and rough surface, mainly in the naval industry. After the wearing process. copper slag retains most of its original properties, and remaining an environmental problem. Chemical composition of copper slag presents a high iron, Silica and Aluminium oxide Content which makes it as a pozzolanic material. Thus, it is possible to use it as a partial replacement for sand in concrete. After a chemical, physical, mineralogical, and environmental characterization of copper slag, it is used as a - partial replacement of sand in concrete was investigated. This project reports on an experimental program to investigate the effect of Using copper slag as a replacement of sand on the properties of concrete .Six concrete mixtures were prepared with different proportions of copper slag of Weight basis ( 0 percent (for the control mix), 15,25 and 30 percentage. Concrete mixes were tested for compressive strength, split tensile strength and flexural strength.
\end{abstract}

\section{Keywords :Copper Slag, Concrete properties, Compression effect.}

\section{INTRODUCTION}

Many countries are witnessing a rapid growth in the construction industry which involves the use of natural resources for the development of the infrastructure. This growth is jeopardized by the lack of natural resources that are available. Natural resources are depleting worldwide while at the same time the generated wastes from the industry are increasing substantially. The sustainable development for construction involves the use of non-conventional and innovative materials, and recycling of waste materials in order to compensate the lack of natural resources and to find alternative ways for conserving the environment. Fine Aggregates are considered one of the main constituents of concrete. In many countries there is scarcity of natural fine aggregates that are suitable for construction while in other countries there is an increase in the consumption of fine aggregates due to the greater demand by the construction industry. In order to reduce dependence on natural fine aggregates as the main source of fine aggregate in concrete, artificially manufactured fine aggregates and artificial fine aggregates generated from industrial wastes provide an alternative for the construction industry. Therefore, utilization of fine aggregates from industrial wastes can be alternative to the natural and artificial fine aggregates. Without proper alternative fine aggregates being utilized in the near future, the concrete industry globally will consume 8-12 billion tons annually of natural fine aggregates after the year 2010. Such large consumption of natural fine aggregates will cause destruction to the environment. In the last few decades there has been rapid increase in the waste materials and by-products production due to the exponential growth rate of population, development of industry and technology and the growth of consumerism. The basic strategies to decrease solid waste disposal problems have been focused at the reduction of waste production and recovery of usable materials from waste as raw materials as well as utilization of waste as raw materials whenever it is possible. The beneficial use of by-products in concrete technology has been well known for many years and significant research has been published with regard to the use of materials such as coal fly ash, pulverized fuel ash, blast furnace slag and silica fume as partial replacements for Portland cement. Such materials are widely used in the construction of industrial and chemical plants because of their enhanced durability compared with Portland cement. The other main advantage of using such materials is to reduce the cost of construction. Copper slag is one of the materials that is considered as a waste material which I could have a promising future in construction industry as partial or full substitute of fine aggregates. It is a by-product obtained during the matte smelting and refining of copper. To produce every ton of copper, approximately 2.2-3.0 tons copper slag is generated as a by-product material. In Oman approximately 400,000 tons of copper slag is produced every year. Also, the production of approximately $0.36,0.244,2.0$, and 4.0 million tons of copper slag is reported in Iran, Brazil, Japan and the United States, respectively. Utilization of copper slag in applications such as substitute of fine aggregates has threefold advantages of eliminating the costs of dumping, reducing the cost of concrete, and minimizing air pollution problems.

Although there are some studies that have been reported on the effect of copper slag as fine aggregates on the performance of normal strength concrete, there has been little research concerning the incorporation of copper slag as fine aggregates to produce concrete. Thus this research was performed to evaluate the potential use of Copper slag as sand replacement in the production of concrete.

\section{MATERIALS USED}
A. Cement
. Ordinary Portland cement (OPC) of 53 grades available in market was used in investigation. The cement used has 
been tested for various proportions as per IS: 8112-1982. Grade 53 indicate that the cement will attain a compressive strength of $53 \mathrm{~N} / \mathrm{mm} 2$ area after curing period of 28 days.

Table-1 Test on cement

\begin{tabular}{|c|c|}
\hline Test & Results \\
\hline Specific gravity of cement & 3.2 \\
\hline Fineness of cement & 9 \\
\hline Consistency of Cement & $31 \%$ \\
\hline $\begin{array}{c}\text { Initial Setting time of } \\
\text { Cement }\end{array}$ & $30 \mathrm{Min}$ \\
\hline
\end{tabular}

\section{B. Fine aggregate (M - SAND)}

Manufactured sand is a substitute of river sand for construction purposes. $\mathrm{M}$ sand produced from hard granite stone by crushing. The crushed sand is of cubical shape with grounded edges, washed and graded to as a construction material. The size of M-sand is less than 4.75 $\mathrm{mm}$.

Table-2 Test on Fine aggregate

\begin{tabular}{|c|c|}
\hline Test & Results \\
\hline $\begin{array}{c}\text { Specific gravity of fine } \\
\text { aggregate }\end{array}$ & 2.47 \\
\hline Fineness of fine aggregate & 3.32 \\
\hline
\end{tabular}

\section{Coarse aggregate}

Coarse aggregate are the crushed granite stones used for making concrete. Coarse aggregates passing through $22.5 \mathrm{~mm}$ sieve and retaining on $19 \mathrm{~mm}$ sieve used this investigation.

Table-3 Test on Coarse aggregate

\begin{tabular}{|l|c|}
\hline \multicolumn{1}{|c|}{ Test } & Results \\
\hline $\begin{array}{l}\text { Specific gravity of Coarse } \\
\text { aggregate }\end{array}$ & 2.71 \\
\hline Impact value & $22.04 \%$ \\
\hline Crushing value & $39.2 \%$ \\
\hline
\end{tabular}

\section{Copper Slag}

Copper slag is an irregular, black, glassy and granular in nature and its properties are similar to the river sand. In this project, Copper slag used is brought from Sterile Industries India Ltd, Tuticorin. Every ton of copper will generate approximately 2.2-3 tons of copper slag. Sterlite Industries India Ltd produces 400,000t/year of copper and during the process, around 800,000t of copper slag is generated in a year. The chemical traces such as copper, sulphate and alumina present in the slag are not harmful. Copper slag is used in the concrete as one of the alternative materials. It is the waste product of copper from Sterlite Industries India Ltd, Tuticorin. The safe disposal of this waste is a lack, costly and causes environmental pollution. The construction industry is the only area where the safe use of waste material (copper slag) is possible. When it is introduced in concrete as a replacement material, it reduces the environmental pollution, space problem and also reduces the cost of concrete. However, further additions of copper slag caused reduction in the strength due to an increase of the free water content in the mix. Mixes with $80 \%$ and $100 \%$ copper slag replacement gave the lowest compressive strength value of approximately $80 \mathrm{MPa}$, which is almost $16 \%$ lower than the strength of the control mix. The results also demonstrated that the surface water absorption decreased as copper slag quantity increases up to $40 \%$ replacement; beyond that level of replacement, the absorption rate increases rapidly. Therefore, it is recommended that $40 \mathrm{wt} \%$ of copper slag can used as replacement of sand in order to obtain HPC with good strength and durability properties.

Table-4 Test on Copper Slag

\begin{tabular}{|l|c|}
\hline \multicolumn{1}{|c|}{ Test } & Results \\
\hline $\begin{array}{l}\text { Specific gravity of } \\
\text { Coarse aggregate }\end{array}$ & 2.79 \\
\hline Bulk Density & $2.08 \mathrm{~g} / \mathrm{cc}$ \\
\hline Water absorption & $0.18 \%$ \\
\hline
\end{tabular}

\section{E. Water}

Water fit for drinking is generally fit for making concrete. Water should be free from acids, oils, alkalis and organic impurities.

\section{III.EXPERIMENTAL INVESTIGATION}

\section{A. Mix design}

The mix design details for $1 \mathrm{~m}^{3}$ of concrete with partially replaced fine aggregate with copper slag.

Table-5 Weight of materials per $\mathrm{m}^{3}$ (M20)

\begin{tabular}{|c|c|c|l|}
\hline $\begin{array}{c}\text { Water } \\
(\mathrm{kg} / \mathrm{m} 3)\end{array}$ & $\begin{array}{l}\text { Cement } \\
(\mathrm{kg} / \mathrm{m} 3)\end{array}$ & $\begin{array}{l}\text { Fine aggregate } \\
(\mathrm{kg} / \mathrm{m} 3)\end{array}$ & $\begin{array}{l}\text { Coarse } \\
\text { aggregate } \\
(\mathrm{kg} / \mathrm{m} 3)\end{array}$ \\
\hline 197.2 & 453.4 & 647 & 1180 \\
\hline 0.45 & 1 & 1.17 & 2.25 \\
\hline
\end{tabular}

Table-6 Percentage of replacement of Brick bats

\begin{tabular}{|c|c|}
\hline $\begin{array}{c}\text { Percentage replacement of } \\
\text { Copper slag }\end{array}$ & Copper Slag (kg) \\
\hline $15 \%$ & 1.22 \\
\hline $25 \%$ & 2.04 \\
\hline $30 \%$ & 2.44 \\
\hline
\end{tabular}

\section{B. Compression test}

The compressive strength test for cubes was conducted in compression testing machine as per IS 516:1959. The cubes were tested in compressive testing machine at the rate of $140 \mathrm{~kg} / \mathrm{cm} 2 / \mathrm{min}$. and the ultimate loads were recorded. The bearing surface of machine was wiped off clean and the surface of the specimen was cleaned. The specimen was placed in machine in such a manner, load was applied to opposite sides of the cubes such that casted side of specimen was not top and bottom. The axis of the specimen was carefully aligned at the centre of loading frame. The load applied was increased continuously at a constant rate until the resistance of the specimen to the increasing load breaks down and no longer can be sustained. Maximum load applied on specimen was recorded.Below table shows the compressive strength of concrete for various percentage of brickbats replacement at 7 days and 28 days. 
Table-7 Compression test results

\begin{tabular}{|c|c|c|}
\hline Description & $\begin{array}{l}\text { Compressive } \\
\text { strength 7 days } \\
\left(\mathrm{N} / \mathrm{mm}^{2}\right)\end{array}$ & $\begin{array}{l}\text { Compressive } \\
\text { strength 28 days } \\
\left(\mathrm{N} / \mathrm{mm}^{2}\right)\end{array}$ \\
\hline M30 & 23.4 & 36.2 \\
\hline $15 \%$ & 27.54 & 38.2 \\
\hline $25 \%$ & 29.3 & 44.2 \\
\hline $30 \%$ & 27.46 & 37.6 \\
\hline
\end{tabular}

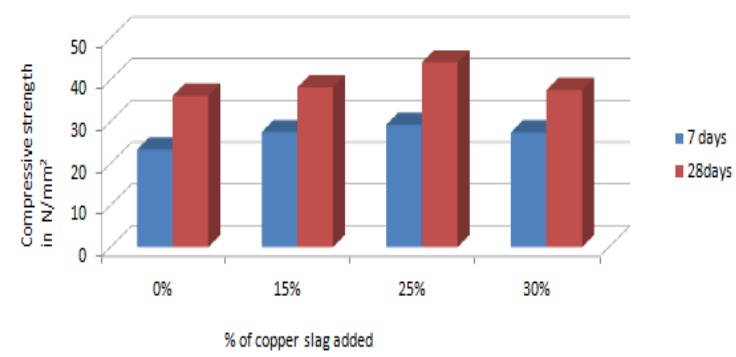

Fig 1: Compressive Strength

\section{Split tensile strength on concrete}

A concrete cylinder of size $150 \mathrm{~mm}$ dia $\times 200 \mathrm{~mm}$ height is subjected to the action of the compressive force along two opposite edges, by applying the force in this manner .The cylinder is subjected to compression near the loaded region and the length of the cylinder is subjected to uniform tensile stress.

Table- 8 Split tensile test results

\begin{tabular}{|c|c|c|}
\hline Description & $\begin{array}{c}\text { Split tensile } \\
\text { strength 7 days } \\
\left(\mathrm{N} / \mathrm{mm}^{2}\right)\end{array}$ & $\begin{array}{c}\text { Split tensile } \\
\text { strength } 28 \\
\text { days } \\
\left(\mathrm{N} / \mathrm{mm}^{2}\right)\end{array}$ \\
\hline M30 & 3.38 & 4.21 \\
\hline $15 \%$ & 3.67 & 4.32 \\
\hline $25 \%$ & 3.78 & 4.65 \\
\hline $30 \%$ & 3.66 & 4.29 \\
\hline
\end{tabular}

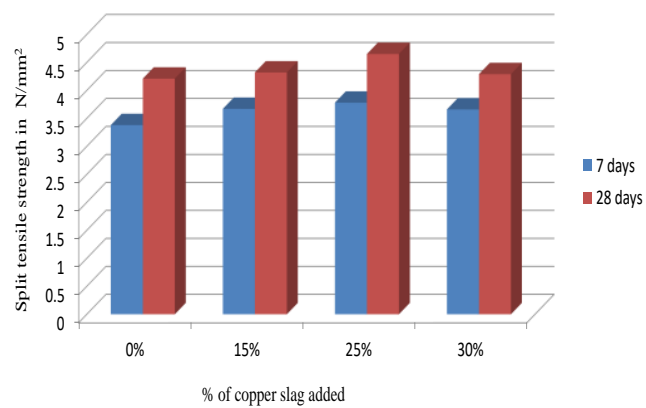

Fig 2: Split Tensile Strength

\section{V.CONCLUSION}

- Addition of up to $25 \%$ of copper slag as sand replacement yielded comparable strength with that of the control mix. However, further additions of copper slag caused reduction in the strength due to an increase of the free water content in the mix.

- It is recommended that up to $25 \%$ of copper slag on weight basis can be used as replacement of sand in order to obtain concrete with good properties.

- It should be noted that further research work is needed to explore the effect of copper slag as fine aggregates on the properties of concrete with different cement types.

- The utilization of copper slag in concrete provides additional environmental as well as technical benefits for all related industries.

- Replacement of copper slag in fine aggregates reduces the cost of making concrete.

- Replacement of copper slag increases the self weight of concrete specimens to the maximum of 15 to $25 \%$.

- $25 \%$ addition of copper slag as fine aggregate in concrete gives more strength compare to $30 \%$ addition of copper slag as fine aggregate in concrete

\section{REFERENCES}

[1] Khanzadi M, Behnood A. "Mechanical properties of high-strength concrete incorporating copper slag as coarse aggregate", Construction Build Mater Vol. 23, Issue 6, Jun. 2009, pp. 2183-2188.

[2] Bipra gorai, R.K. Jana, Premchand, "Characteristics and utilisation of copper slag - a review", Resources, Conservation and Recycling, Vol 39,2003,pp. 299-313.

[3] Khalifa S. Al-Jabri, Makoto Hisada, Abdullah H. Al-Saidy, and S.K. Al-Oraimi, "Performance of high strength concrete made with copper slag as a fine aggregate", Construction and Building Materials, Vol 23,2009, pp. 2132-40.

[4] F. Li, (1999), "Test research on copper slag concrete", Natural Science Edition,J Fuzhou Univ,Vol 127, Issue 5, pp. 59-62

[5] IS: 383-1970. "Specifications for Coarse and Fine Aggregates from Natural Sources for Concrete", Bureau of Indian Standards, New Delhi.

[6] IS: 456-2000. Plain and Reinforced Concrete. Code of Practice. Bureau of Indian Standards, New Delhi.

[7] IS: 10262-1982, Recommended Guidelines for concrete mix design, Bureau of Indian Standards (BIS), New Delhi, India, 1989. 